\title{
The Mythical Power of the Dual River-System of the Carpathian Basin: The Notion of a Hungarian Mesopotamia ${ }^{1}$
}

\section{Róbert Keményfi}

\begin{abstract}
Gyula Prinz is responsible for the notion of "Magyar Mezopotámia" ['Hungarian Mesopotamia']. The natural basis for this idea is that Hungarian culture developed on the surface of an alluvial plains area. According to Prinz, this sort of natural environment was the precondition of great civilizations based on agriculture. In other words, the intrinsic Duna-Tisza ['Danube-Tisza'] river structure, which is similar to that of the rivers Tigris and Euphrates, would elevate Hungary to the status of a "mesopotamic" country. This, according to Prinz, is how the central Hungarian area could become the distributive core of culture, and how this culture could be radiated towards the neighboring peoples who also lived together with the Hungarians in the Carpathian Basin. According to the mesopotamic thesis, Hungary's "cultural power" therefore "elevated" the cultural level of other peoples who lived on the edges of the Carpathian Basin. Accordingly, the "end" or borderland of Hungary's "core culture" was seen to be located where the territory populated by Hungarians ends, or where the plains area shifts into the Carpathian Mountains.
\end{abstract}

Keywords: River Civilization, Myths, Culture-Creating Power, Hungarian Conquest of the Carpathian Basin

Biography: Róbert Keményfi is a professor in the Department of Ethnology at the University of Debrecen in Debrecen, Hungary. His fields of research include the history of science, ethnicity, and the spatial quality of culture.

1 This paper is a partially rewritten and expanded version of a former study published in German under the title "Kulturelles Grenzgebiet_-kulturelle 'Wirkungskräfte." In Grenzgebiet als Forschungsfeld. Aspekte der ethnografischen und kulturhistorischen Erforschung des Grenzlande. Ed. Petr Lozoviuk. Leipzig: Leipziger Universitätsverlag GmbH, 2009: 55-75. A similar version also appeared in Hungarian as “'Kulturális hatóerõnk” mitikus történeti földrajzi háttere. A magyar Mezopotámia képzete” Korall 31/9 (2008): 101-131. 
Keményfi, Róbert. "The Mythical Power of the Dual River-System of the Carpathian Basin: The Notion of a Hungarian Mesopotamia." Hungarian Cultural Studies. e-Journal of the American Hungarian Educators Association, Volume 8 (2015): http://ahea.pitt.edu DOI: 10.5195/ahea.2015.219

The idea of a "Magyar Mezopotámia" ['Hungarian Mesopotamia'], popularized by the Hungarian geographer Gyula Prinz, has its origins in a complex ideological network and set of processes that emerged in the era of modern nation building, in particular within the context of the formation of ethnic and linguistic proto-communities, and the emergence of a consciousness of national origins. For peoples like the Hungarians who entered this nation-building process late, or in the absence of independent statehood, symbolic, ideological systems emerged to help people trace the historical, and often ancient, quality of their culture back to the antediluvian civilizational cradles of humankind.

The notion of a "Magyar Mezopotámia" was one of many narrative accounts that served this symbolic, ideological purpose in Hungary, at least within the nationalist imagination of one group of intellectuals who sought to "establish" the historical and geographical roots of the Hungarian nation. According to the broadest interpretation of the Mesopotamian concept, Hungary was connected to ancient river (valley) civilizations and to the Turanian peoples inhabiting the area between the Southern Urals, the Caspian Sea, the Aral Sea, and the Tien Shan mountains. These important geographical links, as well as the Sumerian-Hungarian linguistic relationship that grew out of the Turanian idea, helped the Hungarians to gain access to a supposedly secret, and long-since forgotten body of knowledge that, beyond opening up interpretations of the cosmos in its totality, was able to elevate the Hungarian people to the ranks of other culture-creating groups capable of establishing a universal civilization. For advocates of the Mesopotamian idea, all of Hungary's social "problems" and historical tragedies could be traced back to the fact that academic thinking, the development of Hungarian society, and political decision-making have failed to recognize this basic principle. The Hungarians "would not be lagging behind," in other words, if this "ancient cultural power" and "high erudition" (for example, runic writing) could again be mobilized to serve the cause of elevating the Hungarian nation. In the end, it was not just in semi-scientific or "esoteric history writing" that the Mesopotamian idea appeared. Though it was ultimately refuted by professional scientific criticism, the Mesopotamian concept also emerged (although not in the form of a profoundly elaborated tenet) as a theory that presented the Carpathian Basin itself as a peculiar "Hungarian Mesopotamia."

\section{Background in the History of Ideas}

One of the characteristic features of historical myths emerges when a given people, nation, or ethno-political community endeavors to interpret its relationship to a particular space or set of spatial structures (for example, a natural or cultural landscape, state, area, or region), or a location that it considers to be its own. An awareness of the history of geography, therefore, and in particular the origins and evolution of its core notions and postulates, is indispensible when analyzing the myths (and misbeliefs) of national origin. It was in the second half of the nineteenth century that geography in Europe identified and clarified the exact objects and objectives of its investigation. Its central concern was to provide a detailed analysis of the 
Keményfi, Róbert. "The Mythical Power of the Dual River-System of the Carpathian Basin: The Notion of a Hungarian Mesopotamia." Hungarian Cultural Studies. e-Journal of the American Hungarian Educators Association, Volume 8 (2015): http://ahea.pitt.edu DOI: 10.5195/ahea.2015.219

(external) environment, which was considered to be either natural or formed and/or transformed by human interaction. It was within this context that geographers began to focus on the interpretation of the particular spatial relations found within a given environment. As Gábor Strömpl argued: "Geography, as a science of spatial relations, can only focus on the spatial relationships of the (earthly) world of phenomena, in short, its spatial quality" [A geografia, mint térbeli tudomány, a (földi) jelenségvilágnak csak térbeli viszonyaival, röviden térbeliségével foglalkozhatik] (Strömpl 1921: 100). Thus, within the philosophy of geography, the notion of space emerged as a central category of understanding and analysis. Founded upon the notions of space and spatial relations as the fundamental issues of geography, the discipline itself was then gradually divided into two major sub-fields over the course of several decades: physical geography and human geography. The clarification of geography's subject matter, coupled with the development of its main branches of inquiry, provided would-be nation-builders with a sophisticated arsenal of tools, ones with which they could lay claim to scientific objectivity in their analyses of physical as well as human geographical constructions. The notion of space, in turn, proved especially useful in their attempts to legitimize national "historical space."

At the turn of the twentieth century, the producers of nationalist or nation-building geography in Hungary found themselves in a rather convenient (kényelmes) position. Given the existing territorial integrity of the pre-Trianon Kingdom of Hungary, geographers could claim to be employing a neutral scientific approach in their analysis of the spatial processes taking place in the Carpathian Basin. Owing to the fact that it corresponded to natural geographical boundaries, pre-Trianon Hungary, in short, could be presented as a unified physical as well as social unit. The geographical textbooks and scientific studies of the time, in fact, discussed Hungarian state territory as a "természetes kerekded egész" ["naturally compact whole'] (see Prinz 1914: 163-178) and formulated the principle whereby the political space of the Hungarian state "corresponded directly" to the physical space of the Carpathian Basin [magyar államtér egyenlö Kárpát-medence] (Hajdú 2006: 390-417). Indeed, in the first decades of the twentieth century, it was not possible to publish any serious argument questioning the "perfectly organic" [tökéletesen szerves] territorial unity of the Hungarian state. According to the geography of that time period, Hungarian state space was very close to "ideal" [ideális].

This "pleasant" [kellemes] and "geographically also self-legitimizing" [önmagát geográfiailag is legitimáló] state formation was upset by the Trianon peace treaty signed in 1920, as this treaty fundamentally broke up the former territorial formation of the state (Figure 1). If there was (or, rather, if there had been) in the previous decades "some kind of" holistic Hungarian geography, that is to say, a latent state-national perspective that presented the Hungarian state as a unified entity whose naturalness was beyond question, this comfortable, self-assured position was abandoned for good by Hungarian geography in the years following 1920 (Gyáni 2012: 91-115). From this point on, Hungarian geography served "the Hungarian Cause" with all its scientific might, subordinating virtually everything to this chief objective, including the questions asked by geographers and the methodological background used in answering these questions, as well as the theoretical consequences of their research findings. This post-Trianon geography attempted to work out a system of arguments that, running parallel 
Keményfi, Róbert. "The Mythical Power of the Dual River-System of the Carpathian Basin: The Notion of a Hungarian Mesopotamia." Hungarian Cultural Studies. e-Journal of the American Hungarian Educators

to socio-geographical (or, to use a contemporary term, anthropo-geographical) arguments, strove to justify the inviolability of the Hungarian state space and the Hungarian state borders, not only by illustrating this with the exactness of natural sciences (physical geography), but also by "proving" through human geography the deep embeddedness of Hungarian culture in the natural physical environment. That is to say, after 1920 Hungarian geography endeavored to present the divided space of Hungarian culture as a once-perfect unity, and to acquire a new legitimation for the spatial framework of this culture (Hajdú 2006: 390-417).

Conscious as they were of developments in post-World War I Germany, Hungarian geographers were influenced considerably by the German geographical responses to the "shock" suffered by the Germans as a result of Treaty of Versailles signed in 1919. The German influence on post-Trianon Hungarian geography was twofold. On the one hand, Hungarian geographers applied some of the core ideas born in post-Versailles Germany directly to their own studies on the post-war conditions of the Carpathian Basin. On the other hand, they also regarded German ideas and approaches as a sort of encouragement to work out a uniquely Hungarian theoretical system of responses. Naturally, this "térképzési folyamat" ['space-creating process'] also generated its own terminological and methodological basis. In order to justify the landscapetheoretical background of the Hungarian political space, and to thus prove the close connection between the two (i.e., between politics and the landscape), the geographers of this period listed a range of natural geographical reasons. By the 1930s, Hungarian geography could not avoid adopting a standpoint which emphasized spatial structure (térszerkezeti állásfoglalás) in relation to the decisions imposed upon Hungary as a result of the Trianon peace treaty. This geographical approach could be summed up, basically, by the assertion that there should be (or, rather, should have been) no change in conditions after World War I. No physical or human geographical reason could be offered for justifying the new, smaller state as a legitimate geographical whole. The approach adopted by post-Trianon geographers ultimately meant that "for us geographers facing the situation after the Versailles Peace Treaty" [nekünk, a trianoni helyezettel szembesülö geográfusoknak], it was necessary to think "the other way around." 
Keményfi, Róbert. "The Mythical Power of the Dual River-System of the Carpathian Basin: The Notion of a Hungarian Mesopotamia." Hungarian Cultural Studies. e-Journal of the American Hungarian Educators Association, Volume 8 (2015): http://ahea.pitt.edu DOI: 10.5195/ahea.2015.219

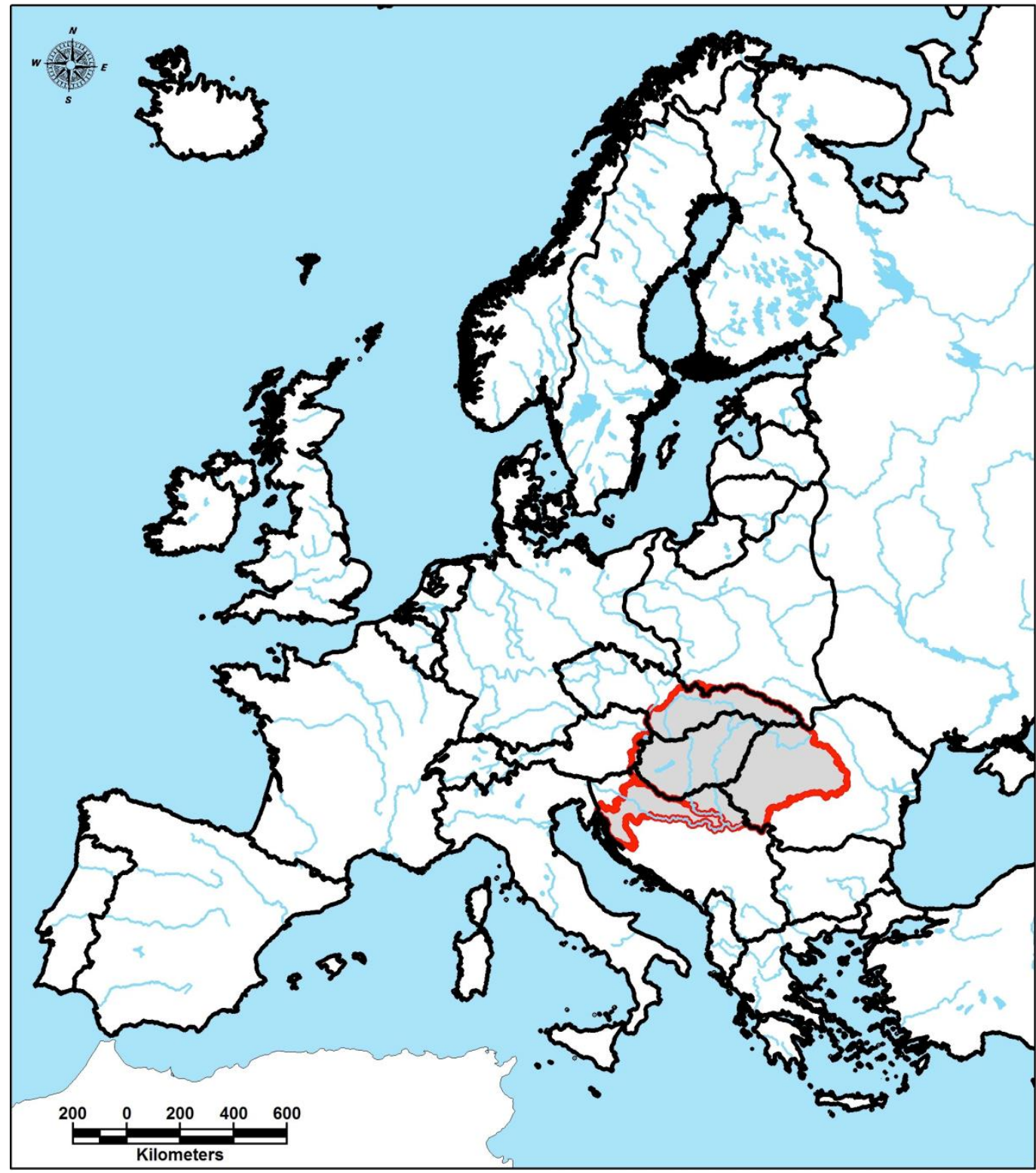

Figure 1. The state borders of Hungary before 1920: — and after 1920: —

In the wake of Hungary's postwar dismemberment, Hungarian geographers strove to prove the stability and unity of the nation's pre-Trianon conditions by offering systematic arguments that underscored the impossibility and untenable nature of the new situation. The task of interwar geography, therefore, was to utilize geographical science in ways that would help present the congruence of territory and state from the viewpoint of major geographical relationships. Hungarian territory, seen in this new light, was not considered merely as a 
Keményfi, Róbert. "The Mythical Power of the Dual River-System of the Carpathian Basin: The Notion of a Hungarian Mesopotamia." Hungarian Cultural Studies. e-Journal of the American Hungarian Educators Association, Volume 8 (2015): http://ahea.pitt.edu DOI: 10.5195/ahea.2015.219

possession of the state. Instead, it was regarded as a unified body inseparable from the people (Prinz 1938: 360). As one of the leading geographers of this period, Gyula Prinz, for example, offered a comprehensive, roughly forty-page-long outline of the integrity of the Carpathian Basin at the beginning of Magyarország a földrajzban ['Hungary in Geography'], the first book in his multi-volume Magyar föld, magyar faj ['Hungarian Land, Hungarian Race'] (Prinz 1936, 15$63)$.

It is important to keep in mind that developments in Hungarian geography after Trianon did not so much diverge from earlier scientific trends, but instead continued to be deeply influenced by them. A survey of the relevant geographical literature of this time period, in fact, reveals not only the historical debt that Hungarian geographers owed to earlier efforts that went into creating "real" spaces out of symbolic social phenomena, but also the individual threads that were used in constructing the imagined fabric of Hungarian national or state space. Running parallel with the establishment of national institutions, and informed by developments around issues of language and culture, Hungarian geography was, of course, deeply influenced by the forms of nationalism that surfaced during the nineteenth century. The process of developing modern nation states naturally gave rise to the gradual "discovery" and expansion of a people's "own national space" [saját nemzeti tér], and with this also the growing importance of the borders of this space. Systems of arguments emerged in an effort to find connections between the people and physical space (the natural environment), and perhaps more importantly to solve the difficult and often mysterious relationship between the two in order to represent the nation as an incontestable notion, or reality.

As in other national contexts, geographical myths appeared within the Hungarian scientific system in order to buttress the arguments and "findings" of the country's nationbuilding elite. Among geographical myths and historical legends, there was a central focus on the correlation between perceived cultural and/or social processes and the environment (physical space). It was within this context that mainstream Hungarian geography drew heavily on Friedrich Ratzel's environmental determinism, and in particular on his idea that the ideal state is created - at least in spatial terms - by filling up the natural environment "granted" to them. In constructing his theory, Ratzel placed a great deal of emphasis on the joint analysis of human societies and the natural environment. In his early works, Ratzel developed and reiterated his position that human activities and forms of organization are determined by the environment. His deterministic approach left a mark on his later works as well. In his study on political geography (1897), Ratzel contended that the position of states in the world determined their political power and global role. The other premise of Ratzel's theory was based on the geographical determinism of the stature of particular cultures/nations (1896).

It is important to note, however, that Ratzel's determinism was by no means simplistic. Ratzel's main tenets, which cite Charles Darwin and Herbert Spencer as authorities, conceives of an environment developed according to the rules of evolution, and shaped by the emergence and influence of a corresponding state space. Thus, according to this concept, nature itself is an organic state organizer. Although the modern Hungarian way of state organization at the end of the nineteenth and beginning of the twentieth centuries gradually gave up its liberal principles as 
Keményfi, Róbert. "The Mythical Power of the Dual River-System of the Carpathian Basin: The Notion of a Hungarian Mesopotamia." Hungarian Cultural Studies. e-Journal of the American Hungarian Educators Association, Volume 8 (2015): http://ahea.pitt.edu DOI: 10.5195/ahea.2015.219

the Hungarian political elite adopted a "German style" approach to nation building, the idea of a unified state space (as opposed to the regional conception of Germany) continued to play a central role in Hungarian political and cultural thinking. Indeed, the concept of the thousandyear-old country of "Szent István" ['Saint Stephen'] as a "Szakrális Egész" ['Sacral Whole'] grew especially strong and influential after 1920 (Zeidler 2007). In fact, alongside Ratzel's assertion that "nature created Hungary through organic correlation as an integral life province" [természet Magyarországot a teljes organikus korreláció által egységes élettartományként teremtette meg] (Prinz 1938: 373) was the idea that "valami több" ['something more'], "valami Nagyobb Erö" ['some Greater Power'] contributed to the establishment of the thousand-year-old natural space of the Hungarian nation. Hungarian geographers of the time differed from the German tradition by embracing a "spiritual" perception of state space, one in which Hungary was "blessed" by the geographical perfection of the space it inhabited. According to Prinz:

The Finno-Ugric race was absorbed by the soil. Yet the language remained, and in its survival the influences of the Lebensraum have been crucial. Any argument that begins from Ratzel's theoretical position, but which suggests that the spreading of a language group is what gives shape to a particular Lebensraum, is mistaken [...]. But Ratzel's theory is right where the spreading of a language overlaps with a physical geographical unit. The spreading of the Hungarians on the flat surface (plate) of their Lebensraum [...] proves the perfection of their Lebensraum. Moreover, the concept of Saint Stephen's state, [...] the specific social life and social structure, $[. .$. and its exceptional development, reveal the proper Lebensraum. This proves that we do not have to adjust the borders of our Lebensraum to these factors [i.e., to the specific social life and social structures of the state]. On the contrary, these factors [the specific social life and social structures, etc.] naturally derive from the unique Hungarian Lebensraum. (Prinz 1942: 128130).

[A finn-ugor vérséget beszívta a föld. De itt maradt nyelv, s ennek megmaradásában az élettér hatása nagyszerüen jut felszínre. Ratzeli elméletböl kiindulva téves az út, mely nyelvnemzet elterjedéséhez akar életteret idomitani [...]. De ezt némi biztonsággal tehetjük ott, ahol a nyelvelterjedés természetes földrajzi téregységhez idomult. [...] A magyarság elterülése az élettér lapos tányérján [...] az élettér tömörségét bizonyítja. [...] Tovább menve, a szentistváni állameszme [...] lényegében más társadalmi élet és szerkezet [...] a sokra képes [...] kirobbanó lendület mind külön élettér jelenlétére vallanak. Nem arra, hogy mindezekhez keresni kell életterük határait, hanem arra, hogy mindezeket természetes fejlödésben sajátságos külön magyar élettér szülte.] 
Keményfi, Róbert. "The Mythical Power of the Dual River-System of the Carpathian Basin: The Notion of a Hungarian Mesopotamia." Hungarian Cultural Studies. e-Journal of the American Hungarian Educators Association, Volume 8 (2015): http://ahea.pitt.edu DOI: 10.5195/ahea.2015.219

The "spiritual" quality of Hungarian space is one of the marked differences between Hungarian and German geographical thinking during this period. Whereas the Hungarians could lay claim to perfect, and even "God-given" boundaries like the Carpathian Mountains that formed a natural eastern border, the Germans had to exert their influence over unbounded geographical space in order to be able to regard it as their own. On the contrary, Hungarians did not need to exert such efforts, and could argue that they were better able to fit into the given (that is, already available, or "adatott") landscape. After World War I Hungarian geographical myths continued to stress the notion that Hungarian life and culture had been shaped within an environment produced by ancient, cosmic forces, and that the conditions created by the Trianon peace treaty—which had failed to take this geographical "reality" into consideration-were therefore untenable, unsustainable, and ultimately unjust.

By the mid-1930s, enough time had passed for the Hungarian practitioners of geography to work out a system of arguments in order to reject scientifically the geographical consequences of the Trianon borders imposed on the nation in 1920. The first three volumes of Prinz's Magyar föld, magyar faj provided ample space to present and elaborate upon the evidence Hungarian scholars had marshaled to support the integrity of Hungary's pre-Trianon borders within the Carpathian Basin. In volume three alone, Prinz offers almost 500 pages of analysis detailing the natural and historical geographical development and constancy of the Hungarian state space. Running alongside and in support of human geographical arguments, Prinz provided a detailed description of the physical geography of the basin. In addition to a detailed summary and explanation of the integrated geological, climatic, and morphological order of the region, Prinz emphasized the organizational power of the state and the space it encompassed, and highlighted the influence of the Carpathian Basin river system. In his discussion of this topic (that is, the connection between state spaces and river systems) in volume one of the same series, Prinz relied on the largely physical geographical assessment of the preeminent Hungarian geographer Jenő Cholnoky. Drawing on relevant international critical literature as well, Prinz's concepts, as it has been noted above, generally rested on viewpoints published in related German scientific sources. Prinz identified his sources not only in his notes and references section, but also in the main body of his text, especially when he cited and borrowed some important or significant ideas from other books or studies. In these instances, he never failed to indicate how he transplanted the specific German idea to the Hungarian conditions. In quite a number of cases, though, he rejects some of the German views either as genuinely useless theories or as ones that are not applicable to the spatial phenomena characteristic of Hungary (Prinz, 1938: 469-475).

\section{River-Systems as External State Organizational Factors}

In Ratzel's thinking on organic states, river systems and their related watersheds are featured as basic pillars, and are seen as having a definite state-organizing power (Ratzel 1896, Ratzel 1909: 169-204). As I have pointed out above, this state-organizing natural feature in Ratzel's concept came in "especially handy" to German geographers in order to be able to lend physical geographical legitimation to the justification of an integral German state space, since, unlike in the case of the northern (sea) border and the unmistakable western and southern 
Keményfi, Róbert. "The Mythical Power of the Dual River-System of the Carpathian Basin: The Notion of a Hungarian Mesopotamia." Hungarian Cultural Studies. e-Journal of the American Hungarian Educators Association, Volume 8 (2015): http://ahea.pitt.edu DOI: 10.5195/ahea.2015.219

(mountain range) borders, the eastern natural geographical borderline could be identified unambiguously only through some kind of a river, in order to legitimize the space of a unified German state from a physical geographical point of view. However, the question of which river to choose for this role remained one of basic importance in German geography, even after the Second World War, ${ }^{2}$ since the state space of the fragile German unity, which was only established in the second half of the nineteenth century, was broken up by the peace treaty concluding the First World War, and was further reduced by the next war. In the responses that followed in the wake of the shock created by the Versailles Treaty, the importance of the (assumed) organizational, state-building spatial power of the river system was greatly enhanced (Schultz 2007: 22-23). German geography in the first half of the twentieth century was extremely successful in presenting the connections between river systems and state space formations, and even exhibited administrative features. Geographers interpreted the unique situation of the Germans in Europe through drawings projected onto maps that traced the systems of rivers. This concept could clearly demonstrate how, in the series of landscape-creating geofactors (for example, relief, soil, and climate), the system of rivers also determined the German national character alongside the historical past and the present. Central systems of rivers were also the perceived factors organizing well-functioning, centrally-oriented state spaces in France, Russia, and in Great Britain (see Figures 2, 3, and 4).

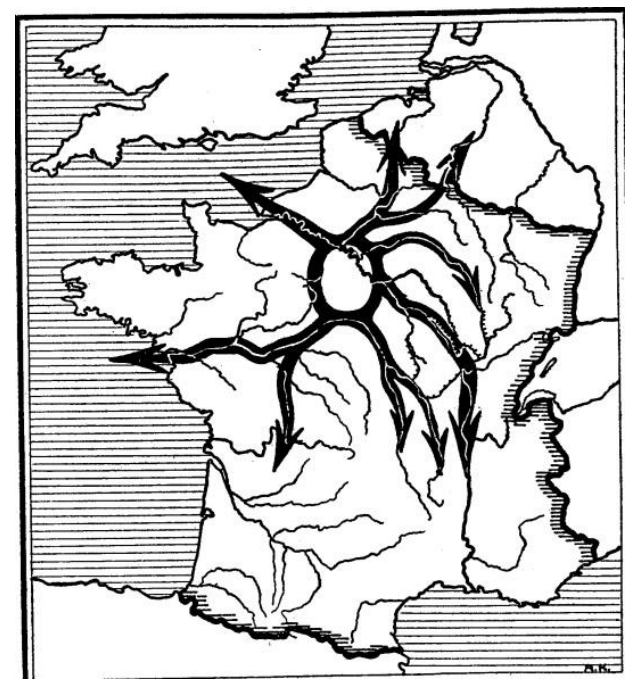

Figure 2. System of rivers supporting French centralism (Obst 1928: 29)

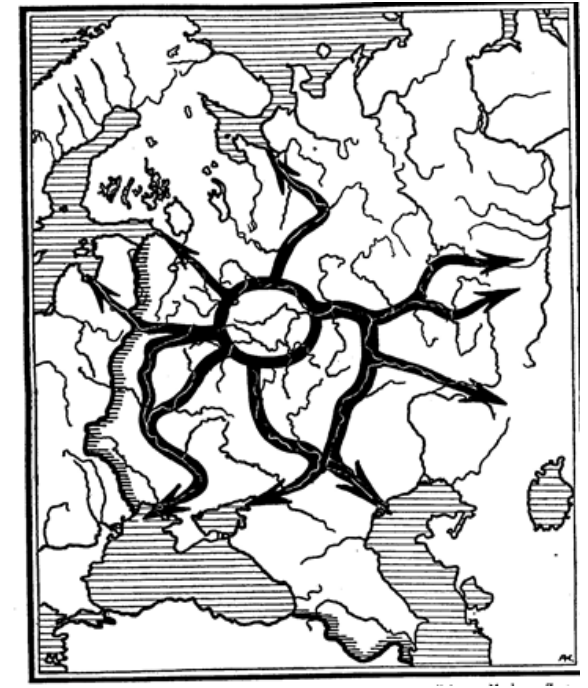

Figure 3. System of rivers supporting Russian centralism (Obst 1928: 31-32)

\footnotetext{
${ }^{2}$ For a discussion of the issue of the rivers Elba-Odera-Neisse-Vistula, and for their cartographical presentation, see Lotz 2007: 67-73.
} 


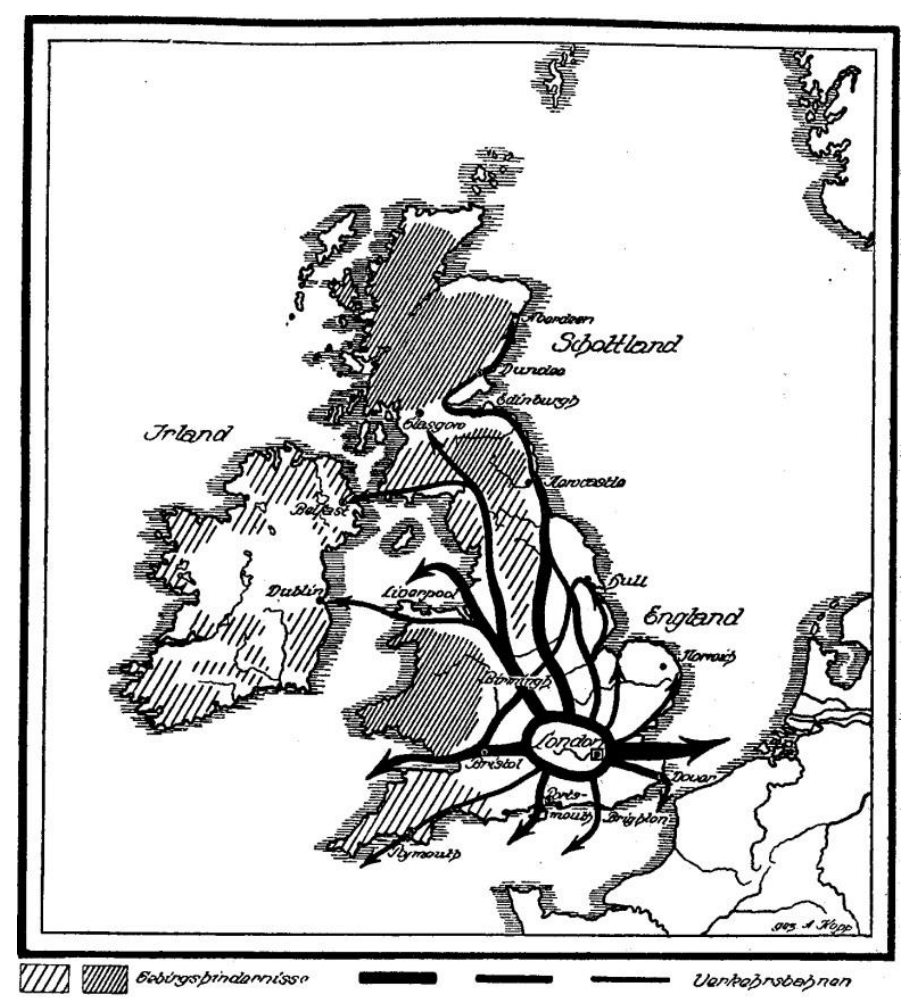

Figure 4. System of rivers supporting English centralism (Obst 1928: 31-32)

Nevertheless, Germany could not be constructed geographically as a centralized state organization, primarily because provincial division had been a characteristic feature of this language area for several centuries. The state is made up of parallel existing spaces of equal rank. This is also confirmed by its river system, as there is no river connection between the Southern, Northern, and East Prussian state parts. These watersheds can be elevated to the status of an integrated state space (Konvergenzraum) only with the help of artificial connecting canals (Figure 5). Yet, this system generates a very important consequence. "Decentralism," as opposed to the case of peoples having a center, produced a diverse and colorful German culture within the state space. As there is no outstanding center, there is no periphery either. During the reconstruction of the German state space following the peace treaty in Versailles, the political elite had to take into consideration this peculiarity, one that was legitimized through its natural geographic character (Obst 1928: 27-40). In fact, this idea already incorporates the so-called "mesopotamic" concept. Although the study also elaborates on the economic and transportation related conditions of the state space as parts of the superstructure, it basically regards German culture to be the result of the river systems. The German cultural space was formed on the diverse but steady (high) quality pattern of huge, independent rivers and watersheds. 


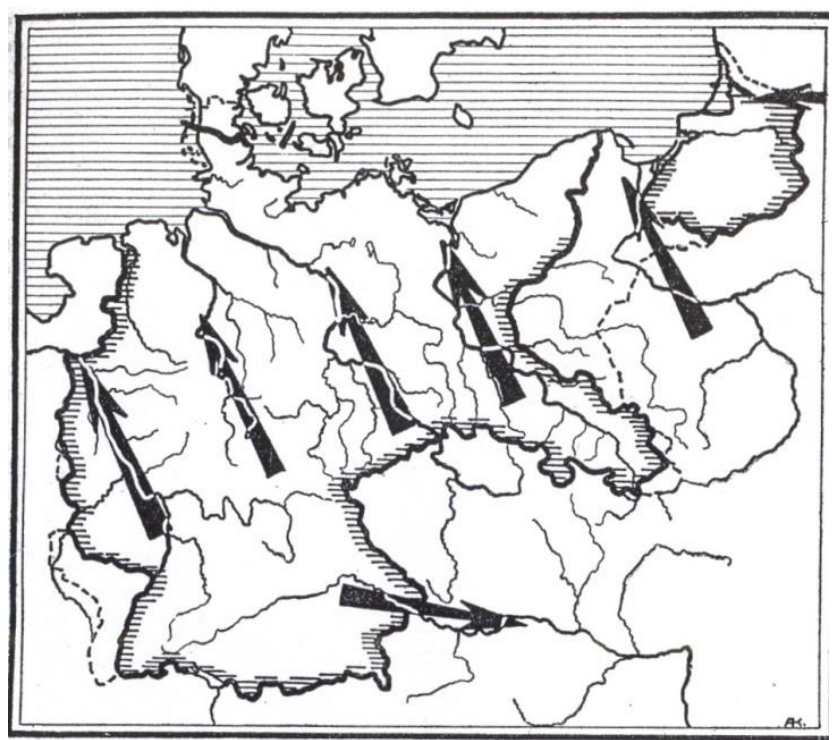

Figure 5. System of rivers in Germany as an obstacle to German centralism (Obst 1928: 33)

If we start browsing through any two of the major Hungarian geographical summaries published between the two world wars, we might easily get the feeling that we are, in fact, looking at consecutive chapters in the same series of books (Cholnoky 1929 and 1937). Although their authors are obviously not the same, their geographical logic is completely coessential. Among the basic fibers making up the fabric of integrated state space determined by the "created" natural geographical environment, we find the waterways of the Carpathian Basin as well. As Teleki argued:

Among the basins, the Hungarian is the biggest. Alongside the chief ranges of the Carpathians, the relief clearly determines the watershed. [...] each river in the basin joins the Danube. [...] Its northern centripetal (running towards the center) center of gravity is the Great Plains; every river and all traffic flows here. [...] Out of all the above, the necessary consequence is that the center and the peripheral parts live in a tight economic symbiosis, and that their peoples are dependent on each other politically as well (Teleki 1936: 418-419).

[A medencék közül a magyar a legnagyobb. A Kárpátok fólei mentén a domborzat világosan meghatározza a vízválasztót. [...] minden folyó a medencén belül egyesül a Dunával. [...] Az északi centripetális (központ felé törekvö); súlypontja az Alföld, minden folyó és forgalom ide lejt, ide folyik. [...] Mindebböl szükségszerüen következik, hogy a központi és a peremi tájak szoros gazdasági symbiososban élnek és népeik politikailag is egymásra utaltak.] 
Keményfi, Róbert. "The Mythical Power of the Dual River-System of the Carpathian Basin: The Notion of a Hungarian Mesopotamia." Hungarian Cultural Studies. e-Journal of the American Hungarian Educators Association, Volume 8 (2015): http://ahea.pitt.edu DOI: 10.5195/ahea.2015.219

This viewpoint could easily be enriched with countless other similar examples, as it reflects the general opinion of the era. The relationship between state space and river systems was explored in greater detail by Gyula Prinz, who wrote: "The nicest expression of the geographical integrity of a country is the spatial configuration of its system of rivers. If it is true that the land of Hungary is a natural unit which is different from its neighbors in exactly the same way that the Hungarian people are a clearly distinct ethnic unit, then this feature must find expression in the network of waterways as well" [Az ország földrajzi egységének egyik legszebb kifejezése folyóvízi hálózatának térbeli alakja. Ha igaz az, hogy a magyar föld éppenúgy a szomszédságától elütő természeti egység, mint amilyen élesen elhatárolt népi egység például a magyarság, akkor ennek a vízrajzi hálózatban is kifejezésre kell jutnia] (Prinz 1938: 189).

Prinz's analyses can be divided into two major parts. One of these is the simple descriptive part, which attempts to answer the question "What is it like?" In the relevant chapters and passages, Prinz presents a detailed description of the network of rivers in the Carpathian Basin. In the descriptive sections, however - that is, in the morphological characterization of the inner part of the basin - Prinz uses the term "mesopotamic" in the original Greek sense of the word ("a country between rivers"). He discusses the interior natural geographic space of preTrianon Hungary as an objective, visible fact, describing it as a country constituted by rivers, and rich in parcels of land between these rivers. Noting the significance of intersecting lines of travel and communication, he contended that "In mesopotamic countries made up of big rivers, like Hungary, the role of crossing points is great" [Nagy folyók mezopotámikus országában, mint amilyen Magyarország, az átkeléshelyeknek szerepe nagy] (Prinz 1938: 189). To this can be added Prinz's claim that "Here, in the 'Mesopotamia' created between the Alps and the Danube and Dráva rivers, a rich and diverse landscape emerged" [Itt az Alpok, a Duna és a Dráva mezopotámiájában a térszín nagyobb gazdagságának hatása érvényesül] (Prinz 1938: 177).

\section{River-Systems as Internal Organizational Factors}

It is one thing to answer the question "What is it like?" It is quite another to answer "Why is it like it is?" A more complex analysis is required, therefore, of Prinz's thinking with respect to the way in which he interprets the inner, genetic relationship between the river system and the Hungarian state space and culture. As I have suggested above, the tools to answer this question had been provided by German geography, and were "in the air at the time" [benne volt a korszak német földrajzának is a levegöjében]. Representatives of Hungarian geography recognized a system of arguments in the German spatial thinking developed after their defeat in World War I and subsequent territorial dismemberment, all of which seemed applicable to a study of the unity of the Carpathian Basin.

The genetic principle of the mesopotamic idea was developed according to the following set of principles. The alluvial plain areas of large rivers create a natural geographical substratum or bedrock which, in a way very similar to that of ancient river valley civilizations, provide the national cultures existing in the given basin with the conditions necessary for cultural emergence (Figure 6). This favorable physical environment is one of the basic pillars of achieving cultural 
Keményfi, Róbert. "The Mythical Power of the Dual River-System of the Carpathian Basin: The Notion of a Hungarian Mesopotamia." Hungarian Cultural Studies. e-Journal of the American Hungarian Educators Association, Volume 8 (2015): http://ahea.pitt.edu DOI: 10.5195/ahea.2015.219

superiority over peoples living on the periphery (that is, over peoples not living in a similarly advantageous environment). Referring to Hungary, Prinz stated that:

Life obviously thrives in the middle, whereas it only vegetates idly on the margins. Up until now, according to the testimony of history, all first-rank educational centers were in the proximity of the center of a land surface well known in its own time.[...] The middle of the stage and, consequently, the stem of life space, is made up of the (Hungarian) Great Plain (Prinz 1938: 24, 45).

[Az élet belül nyilvánvalóan duzzad, a széleken inkább magárahagyatottan tengödő. Eddig is-a történelem tanusága szerint-minden elsörangú müvelödési központ a maga idejében ismert földfelületnek központja közelében volt.[...] A színpad közepét, s ezzel az élettér törzsét az Alföld alkotja.]

Accoding to Prinz's thesis, such a basin-dwelling and, at the same time, alluviumdwelling nation like the Hungarians owed both their cultural efficiency and capacity for expansion, as well as their assimilating, population-unifying ability to the "given" characteristic features of their physical life space. As the Hungarian geographer Károly Kogutowicz wrote: "The Hungarian dwelling areas, without any enervation, maintained the sources of the ancient force inherent in the Hungarian nation, which resurrected itself again and again over the centuries on the same territory despite all the devastation it had suffered" [A magyar szállásterületek, továbbra is gyengitetlenül, forrásai maradtak a magyar népben rejlö ösi erönek, mely ugyanazokon a területeken évszázadokon át és minden pusztítás u után újra és újraéledt] (Kogutowicz 1930: 100). 
Keményfi, Róbert. "The Mythical Power of the Dual River-System of the Carpathian Basin: The Notion of a Hungarian Mesopotamia." Hungarian Cultural Studies. e-Journal of the American Hungarian Educators Association, Volume 8 (2015): http://ahea.pitt.edu DOI: 10.5195/ahea.2015.219

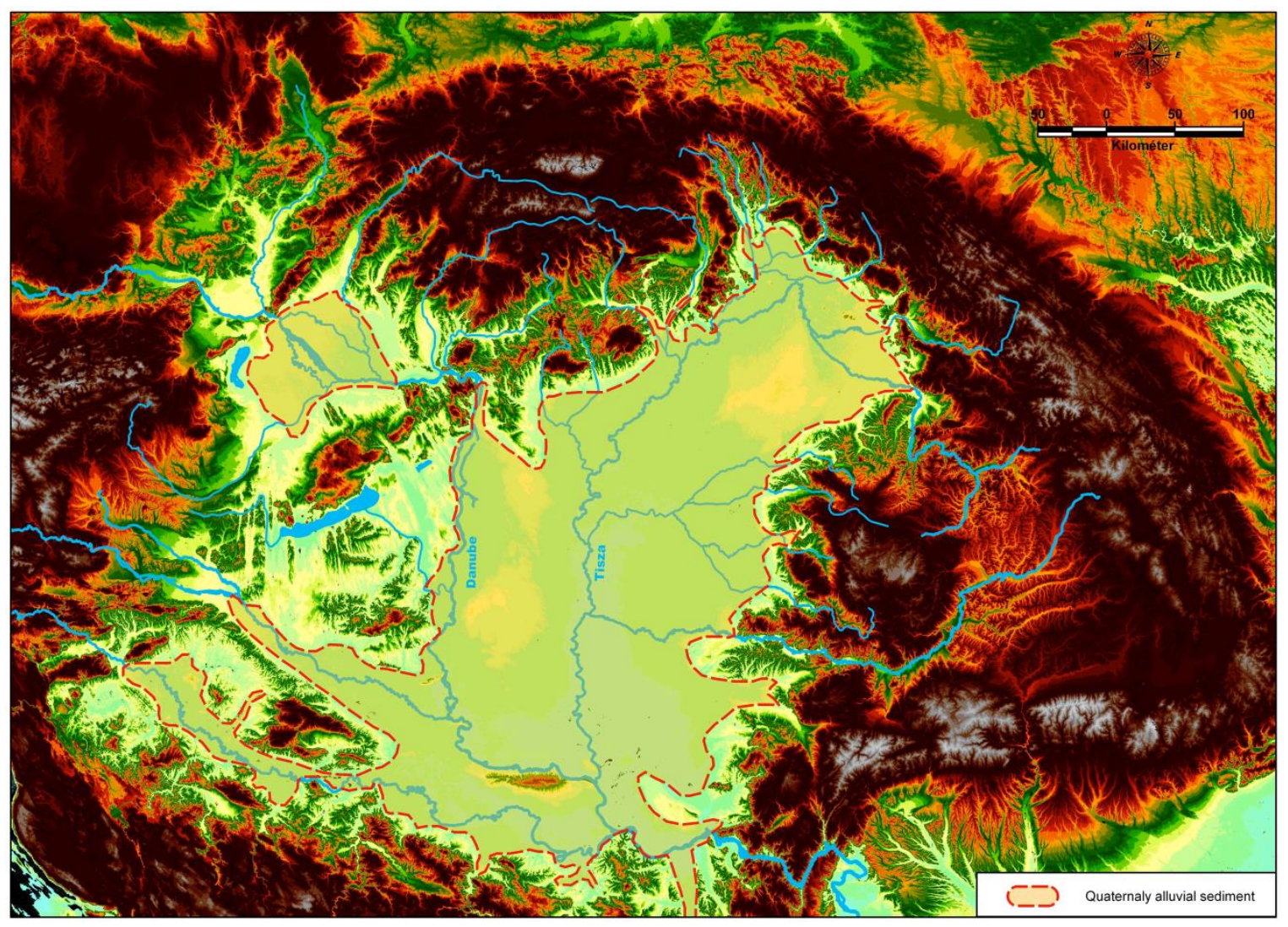

Figure 6. The alluvial territory and borders of the Carpathian Basin in the quarternary period (marked by a broken red line)

The mesopotamic idea articulated by Hungarian geographers like Kogutowicz, fit perfectly, and also subtly, into the theoretical system expressed by Prinz in Magyar föld, magyar faj. What Prinz did for the purpose of analyzing the relationship between Hungarian state space and its physical background was to create an integral theoretical system in which, in addition to the state organizing function of the geological basis, the mountain ranges, the climate, and the relief, we can quite naturally "accept" the "landscape-gives-birth-to-the-state" interpretation of the role of the river system. Moreover, in validating the state-organizing power of the environment, Prinz never simply meant plain borderlines but, behind the format of the state, he always implied national culture, too. Following the relevant sources in the German critical literature, he connected the geographical factors of the landscape (like, for example, climate and tectonic base) to national characterology, and discussed the cultural capabilities of the Hungarians on this uncertain theoretical basis. One of the direct consequences of this perspective was that the river network that constituted this basin was regarded as a cultural germinal area, one that, after an appropriate modification by human agents, became a landscape of the first rank (Prinz 1938: 18). 
Keményfi, Róbert. "The Mythical Power of the Dual River-System of the Carpathian Basin: The Notion of a Hungarian Mesopotamia." Hungarian Cultural Studies. e-Journal of the American Hungarian Educators Association, Volume 8 (2015): http://ahea.pitt.edu DOI: 10.5195/ahea.2015.219

Prinz elaborated on his views by making direct reference to the natural map of preTrianon Hungary. Emphasizing the mesopotamic features of Hungary's core area, he described the Hungarian river system as follows: "If we do not say anything else but the fact that, almost without exception, the bodies of water of the entire country run towards but one single bottom point, we have already expressed the hydrographical unity" [Ha semmi mást nem mondunk, csak azt, hogy szinte maradék nélkül az egész ország vizei egyetlen fenékpontra futnak össze, a vízrajzi egységet máris kifejeztük. Ilyen tulajdonságokkal rendelkezö és ekkora terjedelmü ország kevés a Földön. Földünknek ez különleges, egész polgárosodásunkra kiható értéke] (Prinz 1938: 189). From this hydrographical feature, several social and cultural processes could be explained, according to Prinz, not least of which was the nation's ability to assimilate non-Hungarian populations (Prinz 1936: 55).

Prinz offered a more complete examination of the system of connections between Hungarian culture and the system of rivers in his almost-five-hundred-page-long volume $A z$ államföldrajzi kép ['The State Geographical Picture']. In the subchapters delineating the structure and nature of state space, Prinz repeatedly touched upon the culture-creating power of the hydrographical network and its role in the emergence of the Hungarian people, noting that the Hungarians were somehow destined to create a nation-state where others could not. As he wrote: "the geographical forces must have played an important role alongside the constitutive character of the people. The Germanic tribes [who fought against the Roman Empire in the region in the first, second, and third centuries] were only capable of functioning as warriors on the Great Plain, not as settlers. [...] Yet it is quite clear that, even after the greatest catastrophes, the Pontus-Turanian peoples were able to preserve their national unity on the Great Plain" [földrajzi hatásoknak nagy szerepüknek kellett lenniök a népi szerkezet jellege mellett. A germánok az Alföldön csak harcosok tudtak lenni, de telepesek akkor még nem. [...] De éppen ilyen jól lehet látni azt is, hogy a legnagyobb katasztrófák után is, a pontus-turáni eredetü népek az Alföldön megtudták örizni népi egységüket]" (Prinz 1938: 164). Emphasizing the crucial role that the nation's physical geography played in the formation of modern Hungary, Prinz argued:

In order to draw an accurate picture of the modernization of our country in the nineteenth century, we need to highlight [the physical features] of geography within our history, for the simple reason that we have had to adapt ourselves to our waters [and in particular the rivers]. History in fact illustrates in ways that cannot be assumed just from geography that, since the days of our ancestors, the people of our nation have had a close and vibrant relationship with the country's waters (Prinz 1938: 107).

[Azért kell ezeket a földrajzban a történelemböl kiszedegetnünk, mert vizeinket be kell állítanunk a cselekvö eröknek a sorába, ha az ország polgárosult állapotának képét helyesen megrajzolni óhajtjuk. Mert a történelemböl is kitünik, amit a földrajz másként feltételezni sem tud, hogy az ország népe ösidőktöl fogva életkapcsolatban volt a vizeivel] 
Keményfi, Róbert. "The Mythical Power of the Dual River-System of the Carpathian Basin: The Notion of a Hungarian Mesopotamia." Hungarian Cultural Studies. e-Journal of the American Hungarian Educators Association, Volume 8 (2015): http://ahea.pitt.edu DOI: 10.5195/ahea.2015.219

With regard to the process of state organization, Prinz attached great importance to the adjustments the Magyar people had to make upon their arrival in the Carpathian Basin. Having lived a husbandry-related lifestyle in Asia before their migration, the ancestors of modern Hungarians had to adapt to living around running bodies of water. The forms of agricultural activities in the flood areas, coupled with the establishment of a graticular system and a system of canals - that is to say, the "development of an ancient and authentic mesopotamic model of farming" [ösi, eredeti mezopotamikus gazdálkodási modell kialakitása] — promoted the economic growth of settlements at the time of the Hungarian conquest of the Carpathian Basin. The development of a mesopotamic model also increased the "kulturális hatóerejének" ["cultural efficiency'] of the early Hungarians, as the geographical conditions, and in particular the huge plain area, elevated the "alluvial Hungarians" from their ingressive quality to a culturally expansive people. What happened was that the Hungarians coming to the Carpathian Basin from the outside (through a process of ingression) became a people of high specific gravity living on the plain by having settled on and cultivating the covering strata of the bodies of running water (Prinz 1938, 187; 250-251). According to Prinz, the Hungarians living in the Pannonföld and Alföld areas could thus become the source of a political power capable of forging cultural unity, as this power could more or less integrate, and beyond this assimilate, the other peoples arriving in the Carpathian Basin. The political and economic power of the new Hungarian settlers in the region was also capable of breaking up pockets of non-Hungarian peoples on the margins through the diffusion of Hungarian culture (Figure 7). According to Prinz, the system of relationships built upon ancient river cultures became increasingly important to the lifestyle of the Hungarians, with the socio-economic adjustment to a landscape dominated by running bodies of water setting Hungarians upon a path that gradually led to the development of the middle class, a development which ultimately enhanced the cultural power of the Hungarian people in the long run. Prinz wrote:

First of all, the people-unifying power of the territory of Hungary has not always been so strong, at least as we judge it by looking at the map. With respect to the idea of exerting a forging influence, it has lagged well behind the specifically river-state territories of the world (for example, Egypt, Mesopotamia, China, England). The inner basin area in fact is split into separate stretches by the ancient swampy quality of the land and by the great natural poverty of the river valleys ... The forging capacity of the inner basin area [that is, the Hungarian space] has grown proportionately with the degree of the cultivation of the land and the clearing of transportation obstacles. Since this process in the surrounding mountains cannot keep pace with the basin, the forging power of the Hungarian state territory, especially in relation to the development of the middle class, will increase, and under its influence will grow much faster as the capacity of the mountains as a barrier to development decreases (Prinz 1938: 328). 
Keményfi, Róbert. "The Mythical Power of the Dual River-System of the Carpathian Basin: The Notion of a Hungarian Mesopotamia." Hungarian Cultural Studies. e-Journal of the American Hungarian Educators Association, Volume 8 (2015): http://ahea.pitt.edu DOI: 10.5195/ahea.2015.219

[Mindenekelött Magyarország területének népeket egyesitö földrajzi ereje nem régóta olyan erös, mint azt a térképszemlélet után itéljük. Az összekovácsoló erök tekintetében messze mögötte maradt a kifejezetten folyami (pl. Egyiptom, Mezopotámia, Kína, Anglia) államterületeknek. A belsö medenceterület ugyanis a folyamsávok ösi mocsarassága és természeti nagy szegénysége darabolja szétesö sávokká.[...] A belső medenceterület (ti. a magyar tér - K. R.) összekovácsoló ereje abban a mértékben nö, amilyen mértékben halad a föld megmunkálása és a közlekedési akadályok elháritása. Minthogy a hegykeretben ez sohasem tud emelkedést tartani a medencével, az összekovácsoló erö a polgárosodás emelkedésével kapcsolatban és annak hatása alatt a medencében sokkal gyorsabban nö, mint ahogy a hegykeret akadályozó ereje csökken.]

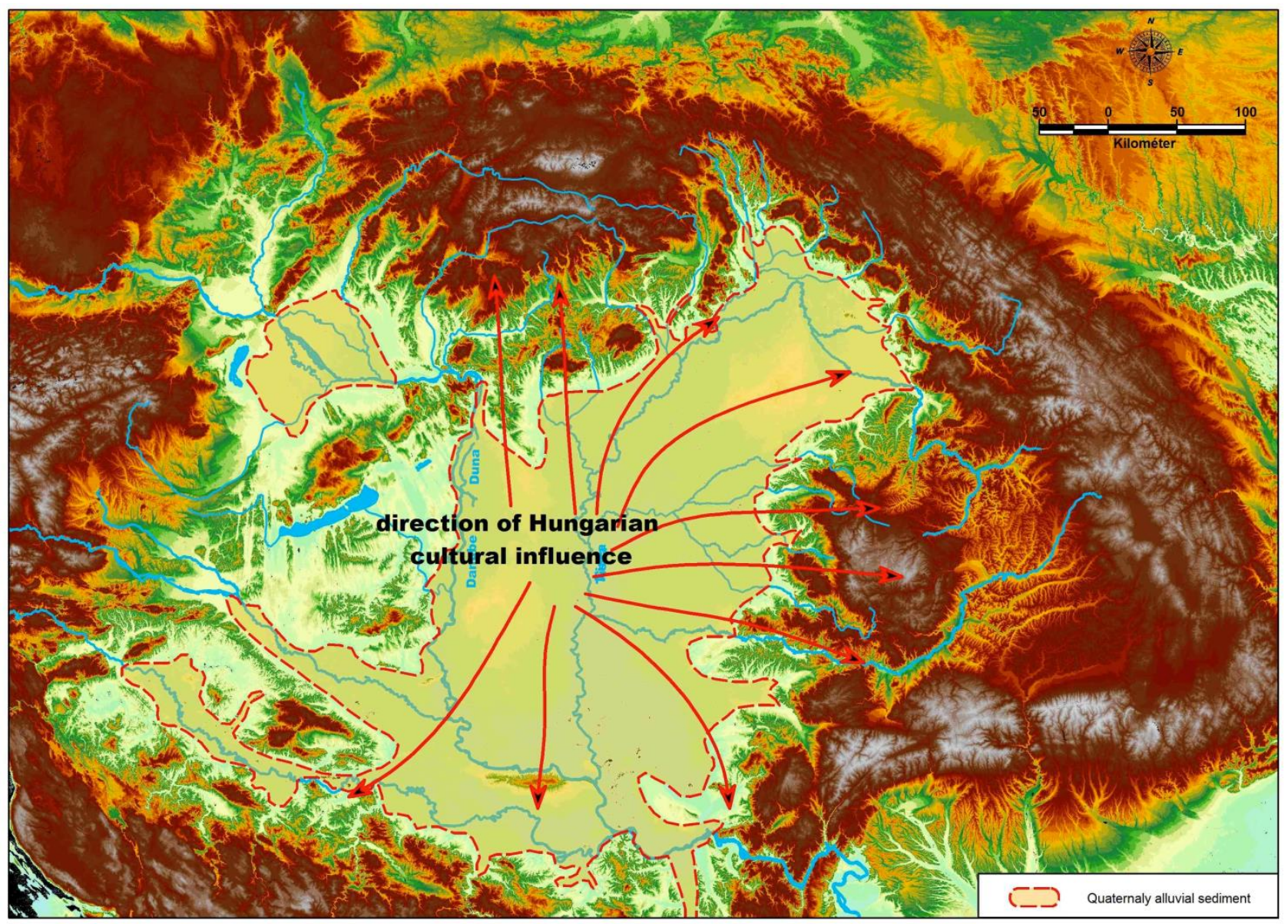

Figure 7. The direction of Hungarian cultural influence in the Carpathian Basin 
Keményfi, Róbert. "The Mythical Power of the Dual River-System of the Carpathian Basin: The Notion of a Hungarian Mesopotamia." Hungarian Cultural Studies. e-Journal of the American Hungarian Educators Association, Volume 8 (2015): http://ahea.pitt.edu DOI: 10.5195/ahea.2015.219

Prinz presents the state organizing power of rivers from two perspectives. From the "space forging power" of rivers in the case of alluvial plain states and their culture, he separates economic geographical assessments of rivers as routes of transportation. The mesopotamic nature of the basin does not mean that the connecting quality of the rivers was as determining as that of the plain areas filled by them (Prinz 1938: 101, 327-328). ${ }^{3}$

If we wanted to summarize Prinz's interpretation of the significance of rivers to the development of the state, and to the process of culture creation, it would be as follows. The Hungarian conquest of the Carpathian Basin was at first primarily focused on the hilly areas in the Pannonföld region (Figure 8). Following this, the nomadic, Turanian population gradually started cultivating the alluvial and loess-covered parts of the Great Plain. The lifestyle changes associated with this adjustment to agriculture led to important shifts in social and cultural practices (for example, the accumulation of property), and enhanced the state organizing ability of the early Hungarians (Prinz 1938: 159, 182, 187).

The principle developed by thinkers like Prinz that identified ethnic groups in particular spaces and landscapes as culture-creating peoples (terekben/tájakban ettnikumok mint kultúrateremtö népek) proved to be very useful for Hungarian ethnography, history, and geography between the two world wars. Representatives of these fields of study, in turn, employed geographical, ethnographical, and historical arguments in order to support and from the center as the ideal natural environment, the closer we find ourselves on the periphery of the core culture (a process referred to as "cultural deterioration"). According to the theoretical framework developed by Hungarian scholars between the wars, in order for the Hungarian and non-Hungarian borderland regions of the Carpathian Basin to popularize claims about Hungary's perfect, geographically-determined, culture-creating ability. The mesopotamic idea expressed - indeed almost modeled - the close connections between the "life strength" and the "life space" (that is, the natural environment) of the Hungarians. According to this concept, the center has natural geographical properties that influence the culture developing around it by means of a conquering "cultural diffusional power." The farther away we gesurvive in the wake of Hungary's territorial dismemberment, they would need to remain connected to the Hungarian core culture. They were, in other words, still dependent on the culture-diffusing power of "Inner Hungary."

\footnotetext{
${ }^{3}$ That is to say, the state geographical role of rivers is rather complex (Prinz 1938: 321).
} 
Keményfi, Róbert. "The Mythical Power of the Dual River-System of the Carpathian Basin: The Notion of a Hungarian Mesopotamia." Hungarian Cultural Studies. e-Journal of the American Hungarian Educators Association, Volume 8 (2015): http://ahea.pitt.edu DOI: 10.5195/ahea.2015.219

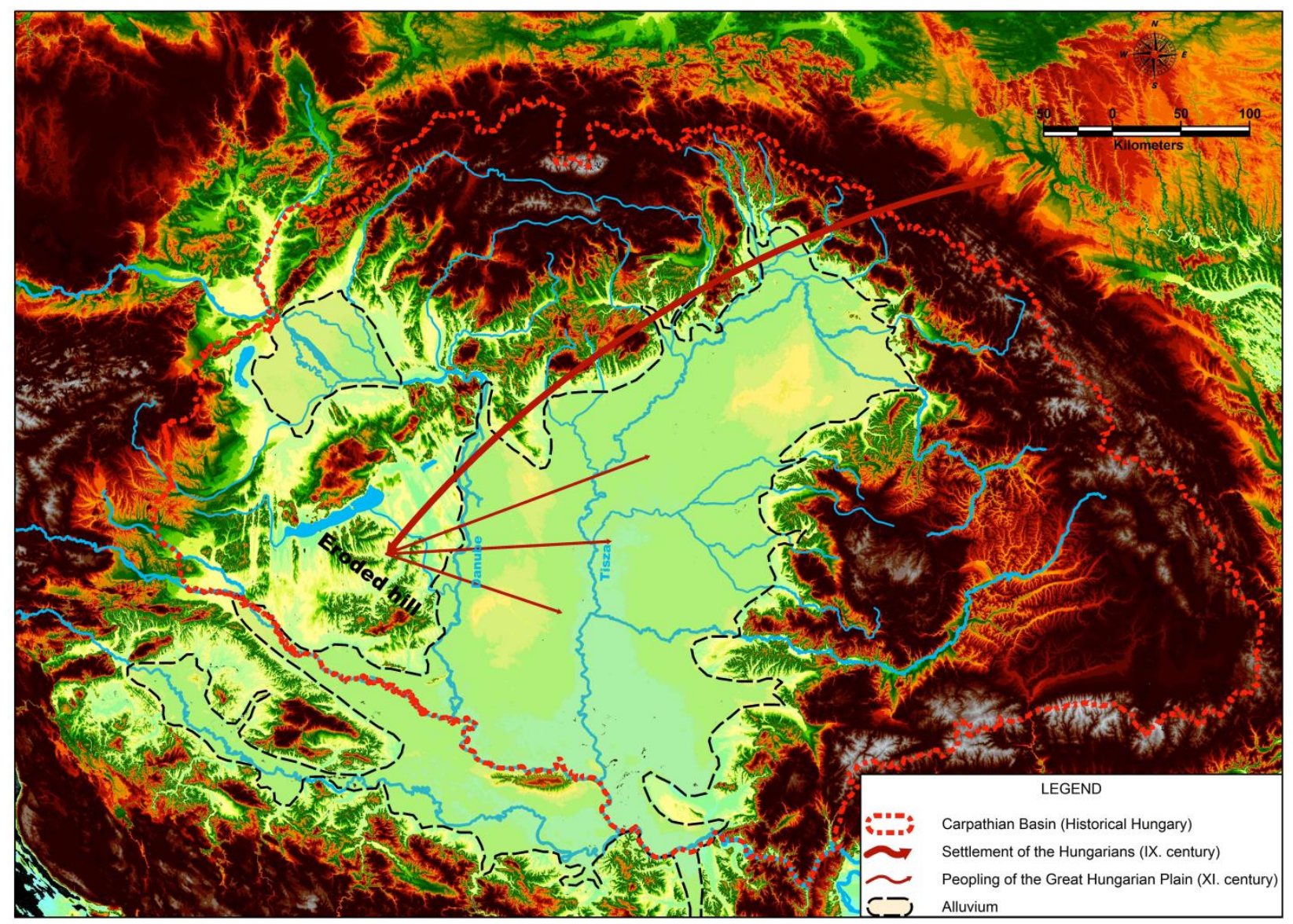

Figure 8. The direction of the Hungarian conquest of the Carpathian Basin

Prinz's mesopotamic concept was naturally embedded within a web of international, if mainly German, geographical works. Ratzel's influence on Prinz, and on Hungarian geographical thinking more generally, was especially noteworthy, in large part because his work was so theoretically rich (if ultimately problematic). Ratzel himself exerted a significant influence, not only on the discipline of geography, but also on cultural anthropology. Ratzel's work also ran parallel with the work of evolutionist researchers who at the time were developing the theory of diffusionism (Taylor 1988: 151-180). As a result of amalgamating the two approaches, a general theory emerged which suggested that, in a given space or environment, the cultures that emerge as higher ranking than the rest will seep into the lowerranking cultures of the neighboring peoples, and will gradually conquer them (adott térben/környezetben magasabb rendüvé emelkedö kultúrák a szomszéd népek alacsonyabb szintü müveltségébe beszivárogva azt fokozatosan meghódítják).

Given that it was an internationally recognized theory, Prinz borrowed from and employed diffusionism in this sense, applying it in the same sense as Ratzel's theories in order to explicate the human geographical processes within the Carpathian Basin. Though cultural 
Keményfi, Róbert. "The Mythical Power of the Dual River-System of the Carpathian Basin: The Notion of a Hungarian Mesopotamia." Hungarian Cultural Studies. e-Journal of the American Hungarian Educators Association, Volume 8 (2015): http://ahea.pitt.edu DOI: 10.5195/ahea.2015.219

anthropologists in the English speaking world had already begun calling attention to numerous questionable aspects of diffusionism, and though scholars more generally had begun to question Ratzel's perhaps overly deterministic link between geography and culture, it is important to point out that Prinz's research, and the work of Hungarian geographers more generally, evolved within an international context within which these ideas and approaches circulated, and had considerable currency. Though he may have applied them in new and novel ways to the Hungarian case, Prinz's ideas were not unique, and belonged clearly and visibly to the general thinking of the given time period. Consequently, it must be emphasized here that the mesopotamic idea employed by Prinz belonged to the general understanding of the scientific community of the times.

The fact that the mesopotamic idea became so popular in the interwar period should not be surprising for another important reason. The territorial consequences of the peace treaty of 1920 were more severe for Hungarians than even the most worst-case scenarios. The popular principle of the time, namely the notion that there was a close connection between state space and the nation, was rejected and ignored by the 1920 peace treaty, ultimately with traumatic consequences. In Hungary, the representatives of Hungarian scientific circles responded by stressing the correlation between landscape and national culture. For our part, as historians of geography, the task remains to situate geographers like Prinz in objective historical context, and to describe his thinking and his works on their own terms. Doing so helps us to keep a proper distance from the object of our inquiry, while simultaneously exploring the historical factors that compelled Hungarian geographical researchers to frame the concepts of their inquiry in the way they did.

\section{Works Cited}

Cholnoky, Jenő. 1929. Magyarország földrajza ['The Geography of Hungary’]. Budapest: Danubia Könyvkiadó.

—. 1937. Magyarország földrajza. A föld és élete. 6. ['The Geography of Hungary: The Earth and Its Life. 6']. Budapest: Franklin-Társulat Kiadása.

Gyáni, Gábor. 2012. "The Memory of Trianon as a Political Instrument in Hungary Today." In The Convolutions of Historical Politics. Ed. Alexei Miller and Maria Lipman. Budapest: Central European University Press: 91-115.

Hajdú, Zoltán. 2006. "A Kárpát-medence és a magyar államterület közötti kapcsolat a Földrajztudományban 1863-1947 között" ['The Relationship of the Carpathian Basin and the Hungarian State Territory in the Discipline of Geography between 1863 and 1947']. In Települések, tájak, régiók, térstruktúrák ['Settlements, Landscapes, Regions, and Spatial Structures']. Ed. Róbert Győri and Zoltán Hajdú. Pécs-Budapest: MTA: 390-417.

Heske, Henning. 1988. „,... und morgen die ganze Welt... ” Erdkundeunterricht im Nationalsozialismus [“"And Tomorrow the Entire World”: Geography Lessons Under National Socialism]. Giessen: Focus Verlag GmbH. 
Keményfi, Róbert. "The Mythical Power of the Dual River-System of the Carpathian Basin: The Notion of a Hungarian Mesopotamia." Hungarian Cultural Studies. e-Journal of the American Hungarian Educators Association, Volume 8 (2015): http://ahea.pitt.edu DOI: 10.5195/ahea.2015.219

Jüngst, P, K. Pfromm, and H.J Schulze-Göbel, eds. 1988. Geographie und Nationalsozialismus ['Geography and National Socialism']. Kassel: Gesamthochschule Kassel

Kogutowicz, Károly. 1930. A Dunántúl és a Kis-Alföld írásban és képekben. I. ['Dunántúl and Kis-Alföld in Writing and Pictures. I'] Szeged: M. Kir. Ferenc József Tudományegyetem Földrajzi Intézete

Lotz, Christian. 2007. "Karten unter Druck. Britische und westdeutsche Wahrnemungen der Oder-Neiße-Grenze in den Debatten um die Kartendarstellung des geteilten Deutschlands (1956-1972)" ['Maps Under Pressure: British and West German Perceptions of the OderNeisse Boundary in Debates over Producing Maps about Divided Germany (19561972)']. In Visualisierung des Raumes. Karten machen — die Macht der Karten ['Visualizing Space: Map Making - The Making of Maps']. Eds. Sabine Tzsaschel, Holger Wild, and Sebastien Lent. Leipzig: Leibniz Institut für Länderkunde: 67-73.

Obst, Erich. 1928. "Zur Neugliederung des Deutschen Reiches" ['On the Reorganization of the German Empire']. Zeitschriften für Geopolitik 5/1-6: 27-40.

Prinz, Gyula. 1914. Magyarország földrajza ['The Geography of Hungary']. Budapest: Magyar Földrajzi Intézet Részvénytársaság. . 1936. Magyarország tájrajza ['The Landscape Geography of Hungary']. In Magyar föld, magyar faj. Magyar Földrajz 1 ['Hungarian Land, Hungarian Race. Hungarian Geography 1']. Budapest: Királyi Magyar Egyetemi Nyomda. . 1938. Az államföldrajzi kép ['The State-Geographical Image']. In Magyar föld, Magyar faj. Magyar Földrajz 3. ['Hungarian Land, Hungarian Race. Hungarian Geography 3']. Budapest: Királyi Magyar Egyetemi Nyomda

—. 1942. Magyarország földrajza ['The Geography of Hungary']. Budapest: Renaissance Könyvkiadóvállalat.

Ratzel, Friedrich. 1896. Der Staat und Sein Boden ['The State and Its Base']. Leipzig: Verlag Bei S. Hirzel. 1909. Antropogehographie I [‘Anthropo-Geography 1']. Stuttgart: Verlag von J. Engelhorns Nachf.

Rössler, Mechtild. 1990. "Wissenschaft und Lebensraum”: geographische Ostforschung im Nationalsozialismus: ein Beitrag zur Disziplingeschichte der Geographie ['Science and Living Space: The Role of Geography in National Socialism: A Contribution to the Disciplinary Knowledge of Geography']. Berlin-Hamburg: Reimer.

Schultz, Hans-Dietrich. 1980. Die deutschsprachige Geographie von 1800 bis 1970 ['German Language Geography from 1800-1970']. Berlin: Selbstverlag des Geographischen Instituts der Freien Universität Berlin. . 2007. "Sie wussten was sie taten! Die propagandistische 'Kraft der Karte"” ['They Knew What they Were Doing: The Propagandistic Power of Maps'] In Visualisierung des Raumes. Karten machen — die Macht der Karten ['Visualizing Space: Map Making — The Making of Maps']. Eds. Sabine Tzsaschel, Holger Wild, and Sebastien Lent. Leipzig: Leibniz Institut für Länderkunde: 13-37. 
Keményfi, Róbert. "The Mythical Power of the Dual River-System of the Carpathian Basin: The Notion of a Hungarian Mesopotamia." Hungarian Cultural Studies. e-Journal of the American Hungarian Educators Association, Volume 8 (2015): http://ahea.pitt.edu DOI: 10.5195/ahea.2015.219

Strömpl, Gábor. 1921. "A geografia mibenléte” ['The Nature of Geography']. Földrajzi Közlemények XLIX: 100-105.

Taylor, Anne-Christine. 1988. "Les modèles d' intelligibilité de l' histoire" ['Modes of Understanding in History']. In Les idées de l' antrophologie ['Anthropological Ideas'] Eds. Philippe Descola, Gérard Lenclud, Carlo Severi, and Anne-Christine Taylor. Paris: Armand Colin: 151-180.

Teleki, Pál. 1936. A gazdasági élet földrajzi alapjai ['The Geographical Foundations of Economy']. Budapest: Centrum Kiadóvállalat.

Zeidler, Miklós. 2007. Ideas on Territorial Revision in Hungary 1920-1945.

Boulder, CO., New York: Social Science Monographs-Atlantic Research and Publications, Inc. 